\author{
S. N. Mondal and L. W. Timmer \\ University of Florida, Citrus Research and Education Center, Lake Alfred
}

\title{
Greasy Spot, a Serious Endemic Problem for Citrus Production in the Caribbean Basin
}

Greasy spot symptoms were first observed on citrus in Florida (4), but the cause of those symptoms was unknown for a long time $(4,46)$. Fawcett (4) described the symptoms in 1936 and suggested greasy spot was due to a nutritional problem or an unknown pathogen. In 1948, Thompson (33) concluded that the problem was due to rust mites (Phyllocoptruta oleivora (Ashmead)) because sulfur applied to control mites reduced greasy spot. However, subsequently, Thompson et al. (34) were unable to reproduce greasy spot symptoms by infesting citrus seedlings with rust mites. In 1956, Yamada (64) reported that a similar disease in Japan was caused by Mycosphaerella horii Hara, which had a Cercospora sp. as the asexual stage. In 1961, Fisher (6) found that the disease was controlled by copper fungicides and subsequently described the causal agent as Cercospora citri-grisea Fisher. A clear understanding of the nature of the disease and the life cycle of the fungus was not developed until the work of Whiteside in the late 1960s and 1970s (4561). He described the causal agent as $M y$ cosphaerella citri Whiteside (50) with a Stenella sp. as the anamorph. The anamorph is now designated as S. citri-grisea (F.E. Fisher) Sivanesan (36). Whiteside demonstrated that ascospores produced in the leaf litter were the primary source of inoculum and described the conditions that favored infection $(46,50,54)$.

Prior to 1940 , greasy spot was not considered to be a serious problem of citrus in Florida. However, during the 1940s, Florida citrus growers realized that greasy spot was causing premature defoliation (57). Prior to that time, citrus growers were using petroleum oils for pest control, and oils are now known to control greasy spot. As organophosphate insecticides replaced oils, greasy spot assumed a greater importance in Florida. The disease causes con-

Corresponding author: L. W. Timmer E-mail: lwtimmer@ufl.edu

DOI: 10.1094/PD-90-0532

(C) 2006 The American Phytopathological Society siderable defoliation and is responsible for reduced yields and fruit size, but those losses have been quantified in only one case. Whiteside (55) found that fungicide applications increased the yield of Pineapple oranges (Citrus sinensis) by $25 \%$.

In addition to losses incurred as a result of greasy spot-induced defoliation, $M$. citri is known to cause a rind blemish on citrus fruit $(46,49)$. Fruit infection by $M$. citri produces a symptom originally referred to as pink pitting. This disease was thought to be caused by a Cercospora sp. (31). Whiteside $(47,49)$ demonstrated that $M$. citri infected through the stomata and killed the guard cells and a few cells surrounding the stomata, producing a tiny lesion. However, when high numbers of infections occurred, a significant blemish developed which he termed greasy spot rind blotch. Greasy spot rind blotch significantly reduces the external quality of fruit for the fresh market. It is a serious problem on grapefruit (C. paradisi), but can also occur on oranges and other citrus. Rind blotch reduces percentage of grapefruit acceptable for the fresh market by 5 to $10 \%$ annually.
Greasy spot is now endemic in all citrus-growing areas of the Caribbean Basin. All of the citrus plantings in Florida need to be treated with fungicides to adequately control the disease. Based on our experience from visits to other areas in the Caribbean Basin, the same is true elsewhere. Most of the leaves on unsprayed trees in the more humid tropical areas are lost each year, with a debilitating effect on tree condition (Fig. 1). Fungicide applications must be made to produce high-quality fruit free of rind blotch.

Greasy spot in areas of the Caribbean Basin outside of Florida is considered to be caused by $M$. citri, but it has been thoroughly studied only in Costa Rica (9). However, the disease is reported to cause significant losses in Cuba $(8,27)$, Trinidad (16), and Surinam (43), especially on grapefruit. Greasy spot also is serious and widespread in eastern Mexico and Belize (L. W. Timmer, personal observations). The disease occurs in Texas (USA), but does not cause serious damage (38) because the climate is drier in Texas than in Florida and most other areas of the Caribbean Basin.

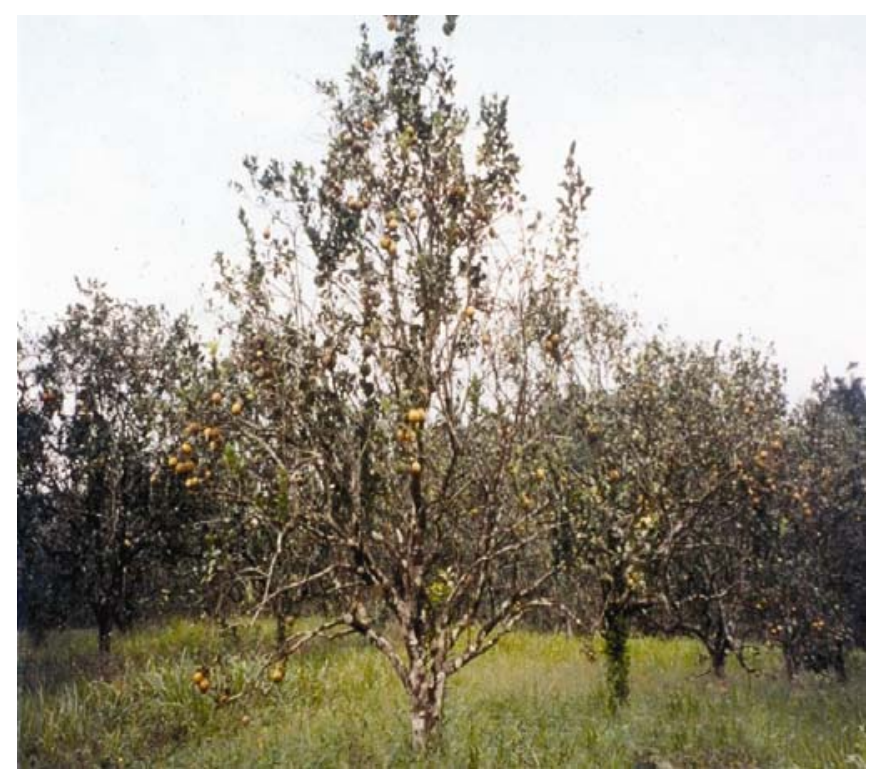

Fig. 1. Sweet orange tree with severe defoliation from greasy spot-induced leaf drop in Belize. 
Similar diseases of citrus have been reported worldwide, but it is not certain that these are caused by M. citri. Gray leaf spot in Japan is caused by $M$. horii and has somewhat different symptoms (36). Pseudo greasy spot in Japan is caused by yeast, Sporobolomyces sp., and also differs in symptomatology (15). However, Ieki (10) described greasy spot in Okinawa and attributed it to M. citri. Greasy spot in Australia (44) and in Argentina (17) have similar symptoms, but may be caused by other species of Mycosphaerella. Greasy spot-like symptoms have been observed in Brazil $(5,29)$, but the pathogen has not been isolated and identified. Symptoms resembling greasy spot have been observed by the authors in Morocco, Korea, and Spain, but nothing has been published in these countries and the etiology of those diseases remains undetermined.

\section{Host Range and Symptoms}

The host range of $M$. citri is limited to the Rutaceae. All Citrus spp. appear to be susceptible to some degree. Whiteside (55) reported symptoms on other genera of the Rutaceae including Poncirus, Fortunella, Murraya, and Aeglopsis, and we have made similar observations. However, it is possible that $M$. citri may not be able to reproduce on some citrus relatives or that another species is involved in the disease of Murraya and other citrus relatives.

Leaf symptoms first appear on mature leaves as a yellow mottle on the upper leaf surface. On the lower surface, a pale yellow area appears that is usually slightly raised. Later, the spots generally turn from yellow to brown to black, and the margins of the lesions usually appear oily. Lesions never become necrotic. Premature leaf drop may leave the tree almost completely defoliated when the disease is not adequately controlled (Fig. 1). Symptoms differ among citrus species. On highly susceptible species, such as lemon $(C$. limon) and rough lemon (C. jambhiri), spots are usually diffuse and tend to remain yellow (Fig. 2A), seldom becoming dark brown or black. On grapefruit, which is somewhat less susceptible, lesions tend to be more constricted, raised, and darker (Fig. 2B). On mandarins (C. reticulata) and late Valencia oranges, which are much more tolerant, lesions are constricted, brown to black, and much more raised (Fig. 2C).

Fruit symptoms are caused when the pathogen enters through stomata and kills a few cells beneath the stomatal opening, causing minute lesions (Fig. 3A inset). Individual lesions are insignificant, but when large numbers of infections occur, lesions coalesce to form a blotchy, very slightly raised blemish (Fig. 3A and B). Symptoms do not develop over the oil glands in the early stages because there are no stomata in those areas. If the disease is very severe, areas of affected rind can collapse and become scarified, sunken, and take on a pinkish cast. Thus, the earlier name for this disease was pink pitting. Rind blotch symptoms can easily be confused with rust mite damage. However, rust mite damage is more contiguous and smooth, whereas rind blotch is a collection of minute, discrete lesions (Fig. 3B). Rust mite blemishes (Fig. 3C) tend to be beige or rust colored, in contrast to rind blotch which is brown to black.

\section{Biology and Disease Cycle}

$M$. citri can be readily isolated from leaf or fruit lesions, but care must be taken to maintain aseptic conditions and to use very small pieces of infected mesophyll. The fungus forms dark, gray-green colonies on most common cultural media. M. citri grows slowly and colonies reach about 2 $\mathrm{cm}$ in diameter after 3 weeks of growth. Conidia are sometimes formed in culture, especially when isolations are first made. Conidia measure 2 to $3.5 \mu \mathrm{m} \times 10$ to 70 $\mu \mathrm{m}$, are multiseptate, pale olive-brown, cylindrical to slightly bent, and verrucose $(36,50)$.

No sexual fruiting structures are produced in greasy spot lesions on living leaves. Pseudothecia on decomposing leaves are aggregated, have papillate ostioles, and measure up to $90 \mu \mathrm{m}$ in diameter $(36,50)$. Ascospores are slightly fusiform, have a single septum, and often contain two oil globules in each cell. They are hyaline and measure 2 to $3 \times 6$ to $12 \mu \mathrm{m}$.

Whiteside $(46,50,54)$ described the disease cycle and the fundamental environmental factors affecting the pathogen. Ascospores of $M$. citri are produced in pseudothecia in decomposing leaf litter on the grove floor (Fig. 4). Once mature, ascospores are forcibly ejected following wetting of the litter and subsequently dispersed by air currents. Ascospores deposited on the underside of the leaf germinate and form epiphytic mycelia. Development of the epiphytic growth requires high temperatures and extended periods of high humidity or free moisture. Appressoria form over stomata, and the fungus penetrates into the mesophyll of the leaf. Nearly all infections occur through the lower leaf surface since citrus leaves have stomata only on the abaxial side. Numerous penetrations are required for development of macroscopic symptoms. Colonization of the leaf is very slow, and symptoms appear only after 45 to 60 days, even on highly susceptible species under optimal conditions. Under grove conditions, infection of leaves occurs mostly in the summer rainy season and symptoms develop in late fall or winter. Symptoms develop more rapidly when winter temperatures are warm (58). Symptomatic leaves abscise prematurely, and most of the greasy spotinduced leaf drop occurs in late winter and early spring. The conidial stage, Stenella citri-grisea, is found in nature only on epiphytic mycelium in late summer (50). Conidia are not believed to play an important role in disease development $(36,46)$.

In more recent work, Mondal et al. (19) demonstrated that $M$. citri is probably heterothallic, as are most loculoascomycetes such as Venturia inaequalis (28), the cause of apple scab, and $M$. fijiensis, the cause of black Sigatoka of banana (25). An in vitro system, developed for production
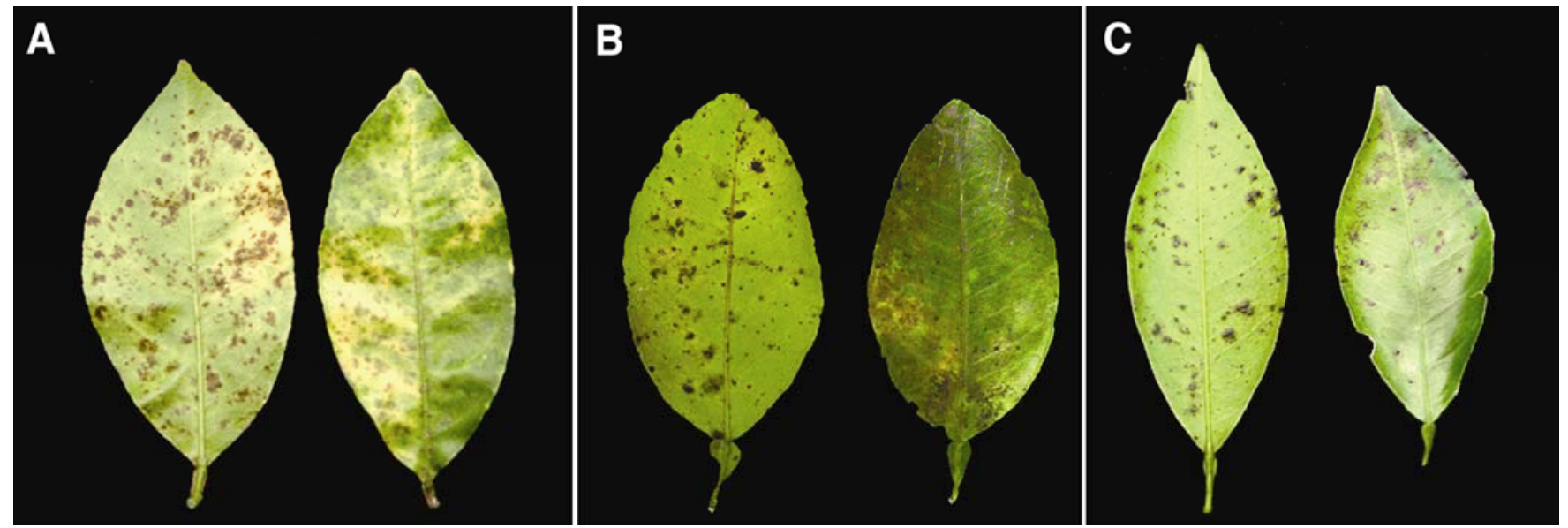

Fig. 2. Symptoms of foliar greasy spot on the upper and lower leaf surfaces: A, rough lemon; B, grapefruit; and C, tangerine. 
of pseudothecia, will facilitate future genetic studies of the pathogen (19). Populations of ascospores recovered from many locations had a 1:1 ratio of mating types, suggesting random mating (19). Development of pseudothecia follows the same pattern as most other loculoascomycetes
$(11,42,63)$. The formation of pseudothecia requires 30 to 45 cycles of wetting and drying.

In more detailed studies of the environmental conditions required for pseudothecial development, Mondal and Timmer (20) found that wetting of symptomatic,
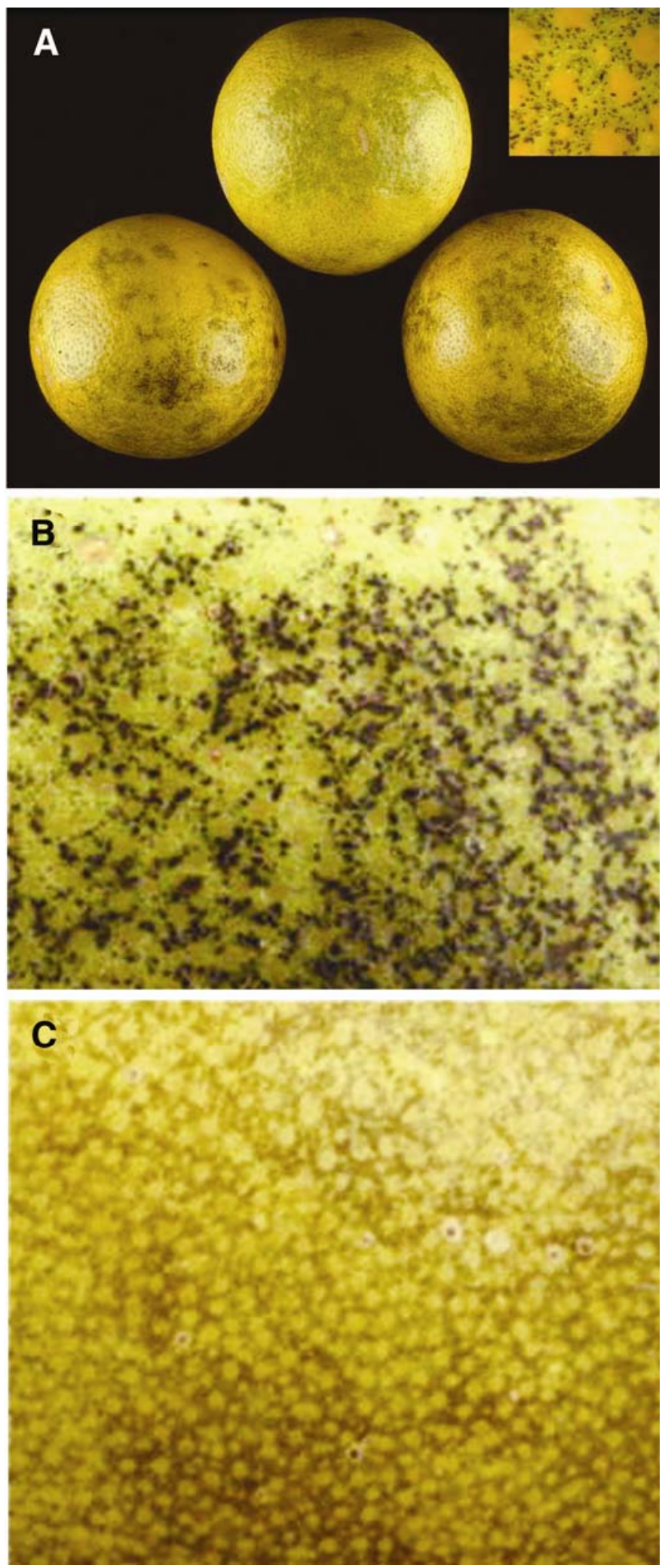

Fig. 3. Symptoms of greasy spot rind blotch on grapefruit: A, rind blotch affected fruit; inset shows a close-up of individual lesions; B, close-up of rind blotch; and C, closeup of damage caused by rust mite.

dead leaves for $3 \mathrm{~h}$ per day 3 days per week resulted in the most rapid pseudothecial development. Shorter wetting times of 10 to $30 \mathrm{~min}$ per day resulted in greater production of pseudothecia and ascospores. More frequent wetting resulted in rapid leaf decomposition, and few pseudothecia were produced. The optimum temperature for pseudothecial formation was $28^{\circ} \mathrm{C}$. In field studies, symptomatic dead leaves placed on the grove floor during the rainy season from June to September resulted in rapid production of pseudothecia. Leaves placed on the grove floor during other seasons produced pseudothecia much more slowly but formed far more pseudothecia and ascospores.

Whiteside (54) demonstrated that only brief wetting of decomposing leaves with mature pseudothecia was required for release of ascospores. Mondal et al. (18) used a computer-controlled environmental chamber to more closely investigate the conditions for ascospore release. Ascospores were released from leaves with mature pseudothecia 30 to $60 \mathrm{~min}$ after a wetting of leaves for $30 \mathrm{~s}$. High relative humidity, red/infrared light (660 to 880 $\mu \mathrm{m})$, and vibration were ineffective in triggering ascospore release. After three to four wetting and drying cycles, all pseudothecia had matured and released their ascospores. In the field, ascospores were detected about $2 \mathrm{~h}$ after the beginning of a rain or an irrigation. Ascospore numbers diminished linearly with horizontal distance from the source and as a function of the logarithm of ascospore numbers with vertical distance.

\section{Epidemiology and Pathology}

Environmental effects. In Florida in 1970, Whiteside (46) found that the peak of ascospore production occurred in June and July (Fig. 5) and that infection of trap plants coincided well with the peaks in ascospore production. In more recent years, we have found that peak ascospore production occurred earlier in April and May $(22,37,39)$. We have speculated that the change in the time of ascospore release was due to changes in cultural practices. Spring time is typically dry in Florida, and in the 1970s, groves were not irrigated or were irrigated every 2 to 3 weeks by traveling gun or overhead sprinkler irrigation. Currently, groves typically have microsprinkler irrigation and are watered two to three times per week when there is no rain. More frequent wetting and drying appears to have accelerated the maturation of pseudothecia and ascospores.

Advancing the peak of ascospore production from the summer rainy season to the spring dry season would be expected to considerably reduce disease severity. However, that does not appear to have happened. The epiphytic mycelium on spring growth leaves develops only when the summer rainy season begins (22), much as 
when Whiteside (55) conducted his studies (Fig. 6). Ascospores are short-lived and perish quickly if exposed to low relative humidity (54). Thus, under current conditions, the relatively low numbers of ascospores produced during the rainy season (22) must be sufficient to establish enough epiphytic growth to cause considerable disease. Mondal and Timmer (23) demonstrated that $M$. citri produces epiphytic growth on the fruit surface as much as it does on leaves.

Other changes in cultural practices may have contributed to increased disease severity. In the 1960s and 1970s, weeds were controlled by cultivation, and thus much of the decomposing leaf litter was buried, preventing production or release of ascospores. In addition, weeds probably interfered with dispersal of ascospores from leaves remaining on the surface. Currently, weeds are controlled by herbicides, and leaves fall on a relatively weed-free surface that is not tilled and is irrigated two to three times per week. Thus, production and dispersal of ascospores is optimized even though the timing of ascospore release is not optimal for maximum infection.

Growth of $M$. citri in the leaf mesophyll is very slow, and many penetrations are required for macroscopic symptoms to develop. The pathogen produces ethylene which eventually induces premature defoliation (7). Usually, symptoms are quite severe before leaves drop, but if a lesion forms near an abscission zone, abscission can occur with little infection. Leaf drop that occurs prior to the occurrence of the spring flush of growth is considered detrimental to the tree.

Arthropod effects. As mentioned previously, greasy spot was attributed to rust mite damage in earlier years. There is evidence that greasy spot is more severe where rust mite populations are high. Van Brussel (43) demonstrated that treatments with acaricides substantially reduced greasy spot severity. Timmer et al. (38) also demonstrated that greasy spot was much less severe where rust mites were well controlled. However, the mechanism of this interaction is unclear. Whiteside (60) subsequently demonstrated that acaricides of diverse chemistry such as chlorobenzilate, cyhexatin, dicofol, and sulfur can provide substantial direct control of greasy spot in the absence of mites.

Whiteside (54) demonstrated that nutrients such as sucrose applied to the leaves increased epiphytic growth and disease severity. Since insects such as whiteflies, aphids, and mealy bugs produce honeydew that increased growth of the pathogen and greasy spot severity (54), effective mite and insect control can help to reduce greasy spot severity.

\section{Disease Management}

Crop protection products. Greasy spot is relatively easy to control with welltimed sprays of many products. The epiphytic growth on the leaf surface is exposed and readily killed by many materials. The products that have been traditionally used for control of greasy spot

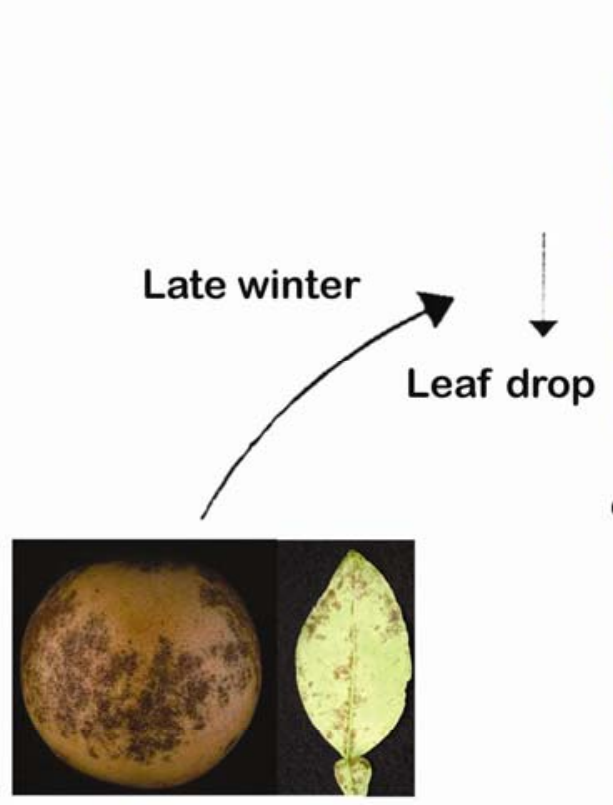

Leaf \& fruit symptoms- winter

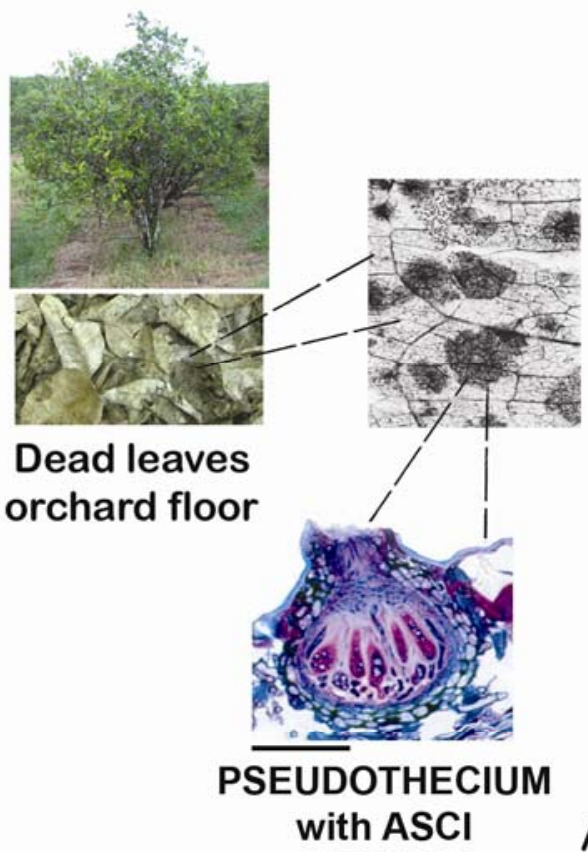
with ASCI

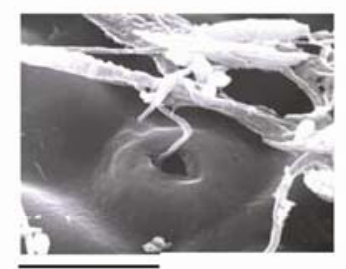

Infection through stomates
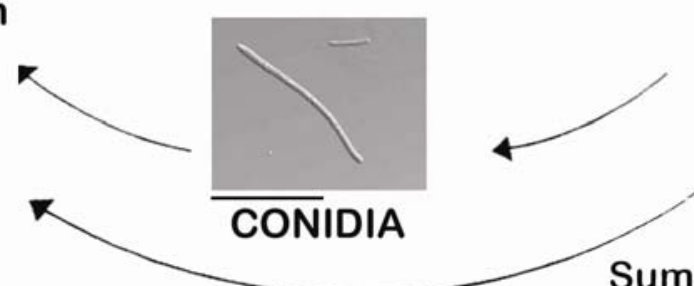

Underside of leaf Epiphytic growth

\section{PSEUDOTHECIA on decaying leaf}
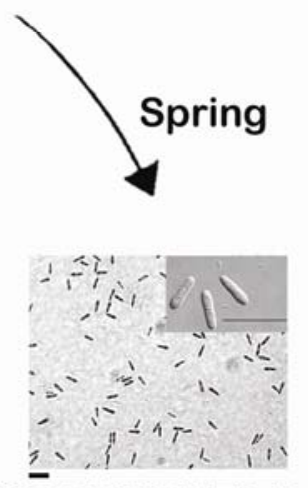

ASCOSPORES forcibly ejected airborne

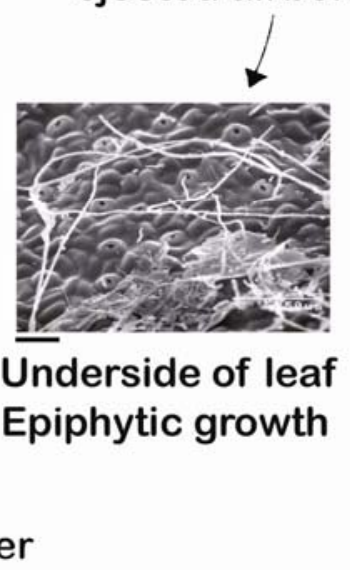

Fig. 4. Disease cycle of greasy spot caused by Mycosphaerella citri. Bars beneath each figure equal about $25 \mu \mathrm{m}$. 
are copper fungicides and petroleum oils $(31,36,52,59,62)$. Copper fungicides directly kill germinating ascospores and epiphytic mycelium and prevent infections. The activity of oil for control of greasy spot has been investigated (51) but is still not well understood. Oil does not appear to inhibit ascospore germination or germ tube growth, but does prevent leaf penetration. It also slows fungal development in the mesophyll and symptom development. Petroleum oils are widely used for control of diseases caused by Mycosphaerella spp., such as yellow Sigatoka disease of banana (3), but their activity is not well understood in those cases either (26). Petroleum oil controls foliar infection but has not been highly effective for rind blotch control (59). However, we have found that the higher viscosity oils used in more recent years also effectively control rind blotch $(1,35)$.

Dithiocarbamate fungicides have also been used in the past $(6,31)$, but they have a relatively short residual activity and are not highly effective. When benomyl was introduced, it was widely used and very effective for foliar and fruit symptoms

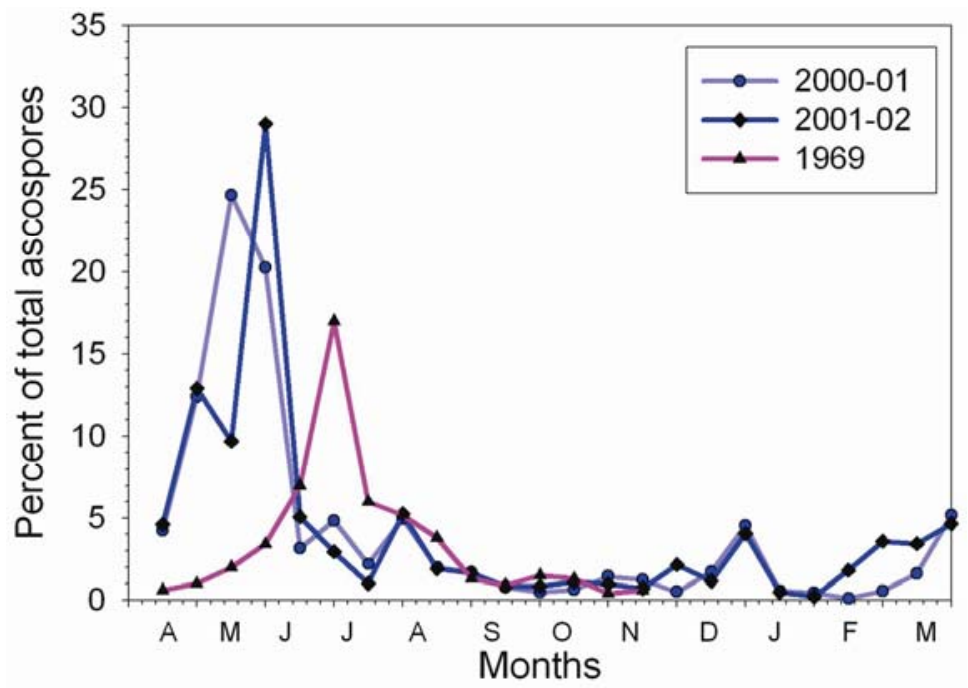

Fig. 5. Timing of ascospore release in Florida citrus in recent years, as compared with 1969.

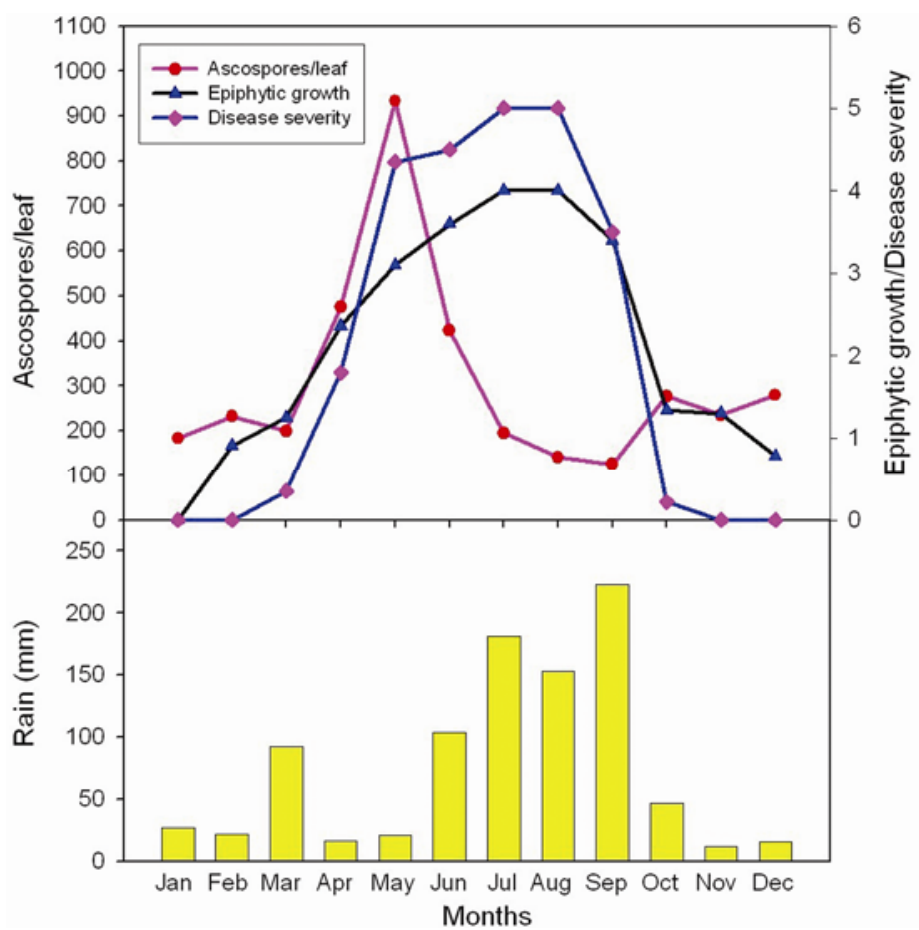

Fig. 6. Typical patterns of rainfall, ascospore release, and disease development on citrus in Florida. Ascospores are in relative numbers and epiphytic growth is on a scale of 0 to 5 based on density. Disease severity is rated on a scale of 0 to 5 on rough lemon trap plants placed in the field weekly during the season. Numbers are the average of data collected in the 2000-01 and 2001-02 seasons.
$(48,59)$. However, resistance developed quickly (56), and none of the benzimidazole fungicides are currently recommended for greasy spot control (40). Fenbuconazole and the strobilurin fungicides are quite effective for control of foliar disease and rind blotch $(1,12-14)$ and are currently recommended in Florida, along with petroleum oils and/or copper fungicides (40).

Foliar fertilizers, especially those containing heavy metals such as zinc, manganese, and iron, are quite effective for greasy spot control if applied at sufficiently high rates (41). Other nutritional products, fish oils, and biocontrol agents have all shown at least some activity against greasy spot (12-14). Acaricides are also active on greasy spot $(12,60)$. It appears that they act directly rather than indirectly through action on mites that aggravate disease since acaricides are effective in the absence of mites. It appears that any product that is toxic to epiphytic mycelium will reduce greasy spot severity if applied at the proper time.

Whiteside (45) evaluated the effect of application of fungicides to the foliage on subsequent production of pseudothecia on decaying treated leaves. Most fungicides had no effect, but benzimidazoles delayed the formation of pseudothecia. In other tests, he applied copper fungicides, captafol, chlorothalonil, and benomyl to decomposing leaf litter (53). Only benomyl substantially reduced inoculum production, but only for 4 to 6 weeks.

Timing of applications. In Florida, greasy spot is rather easy to control on spring growth leaves that usually form in March. Sprays applied any time in May or June provide the best control of the disease on spring growth leaves, and sprays applied in April or even July are quite effective $(39,61)$. In greenhouse tests, applications made 30 to 40 days before inoculation and up to 20 days after inoculation provided excellent control (24). In Florida, one spray from mid-May until the end of June is recommended (40). A single application of an effective product such as fenbuconazole provides impressive control. Leaves that emerged in March that were sprayed in June had very low disease and no defoliation 15 months after emergence (22). When sprays were delayed until August, disease on spring growth leaves was severe, with considerable defoliation. Leaves never develop resistance to the pathogen with age, and recently emerged and mature leaves are equally susceptible (24).

In Costa Rica, ascospore release occurs in May and early June, coincident with the beginning of the rainy season there (9). Applications of a copper fungicide in early June and early August provide good control (9).

Control of the disease on the summer flush growth in Florida and elsewhere is much more difficult. Leaves emerge when 
ascospore numbers are rather low but conditions are optimal for development of epiphytic growth and infection. Thus, sprays usually must be applied within 3 to 4 weeks of emergence of shoots (22). Summer growth flushes in Florida, in contrast to spring growth, do not emerge uniformly and may occur sporadically all summer. Growers in Florida usually apply the first spray in May or June and a second one sometime in July or August (40). The second spray is usually applied after a significant amount of summer flush has emerged. In tropical areas, growth flushes are sporadic throughout the year and more dependent on rainfall than temperature, making the disease difficult to control.

The approach to timing fungicide application on fruit differs slightly. Epiphytic growth develops on fruit at the same time it develops on leaves (23). Applications made in May are not highly effective, probably because of fruit growth between application and onset of epiphytic growth. Sprays in September apparently are too late to have much effect. The key spray for rind blotch control is the one made in July, but monthly applications in June, July, and August are needed for a high degree of control. Thus, typically the first spray is applied from mid-May through June to protect spring growth, and a second spray is applied in July for control on summer flush leaves and on fruit. A third may be added in August to maximize rind blotch control on fruit for fresh market.

Other management practices. Applications of lime and nitrogen fertilizers have been used with some success with apple scab, another disease caused by a loculoascomycete $(2,30,32)$. With greasy spot, Mondal and Timmer (21) found that applications of urea to leaf litter reduce production of pseudothecia and ascospores by up to $90 \%$. Urea releases ammonia gas, which is apparently toxic to $M$. citri. Urea application slows rather than accelerates leaf decomposition, probably because ammonia gas also is toxic to the organisms responsible for decay. In contrast, lime and additional irrigations accelerate decay, and leaf tissue is decomposed so rapidly that pseudothecia never form.

The value of reducing inoculum may be questionable, however. As mentioned above, it appears that most of the infection now occurs well after the peak in ascospore production. In greenhouse tests, inoculation of seedlings with $10^{4}$ conidia per $\mathrm{ml}$ resulted in severe greasy spot that developed rapidly (24). Reducing the dose to $10^{3}$ or $10^{2}$ per ml reduced severity and delayed development of symptoms, but the disease still developed. Even 10 conidia per $\mathrm{ml}$ caused some disease eventually. Reducing inoculum may have benefits, but a high percentage of the inoculum will have to be eliminated to gain advantages from fertilizer treatments. Also, leaf drop is not synchronized in citrus. The peak in
Florida occurs in late winter and early spring, but some leaves drop year-round. Thus, more than one fertilizer or irrigation treatment to reduce inoculum may be needed to eliminate most of the inoculum.

\section{Conclusion and Future Perspective}

The basic biology, disease cycle, and management strategies for citrus greasy spot in Florida are well-understood. With our ability to produce sufficient numbers of ascospores for inoculation studies, it will be possible to better define the environmental conditions required for development of epiphytic growth and infection. With that information, we should be able to develop predictive models that will help us better understand the importance of ascospore dose to disease severity. A better understanding of the mechanism of the effects of mite and insect infestations would facilitate integration of pest and disease control.

The basic principles of the disease cycle are probably applicable to other citrus areas in the Caribbean. However, greasy spot has only been investigated in Texas (38) and Costa Rica (9). Additional studies in other areas on the effect of environmental conditions on disease development would be helpful. Currently, the only recommendation that can be made to growers in other areas is to protect every major flush of growth with fungicides within a month of emergence.

\section{Acknowledgments}

We gratefully acknowledge the assistance of Gretchen Baut (University of Florida, CREC) in preparation of the illustrations and the contribution of photographs of trees defoliated by greasy spot by N. A. Peres (University of Florida, GCREC).

\section{Literature Cited}

1. Bhatia, A., Tesoriero, A. J., and Timmer, L. W. 2002. Evaluation of fungicides for control of greasy spot on grapefruit, 2000-2001. Fungic. Nematicide Tests. Online, Report 57:M02. DOI.10.1094/FN57.

2. Burchill, R. T., and Hutton, K. E. 1965. The suppression of ascospore production to facilitate the control of apple scab (Venturia inaequalis (Cke.) Wint). Ann. Appl. Biol. 56:285-292.

3. Calpouzos, L. 1966. Action of oil in the control of plant disease. Annu. Rev. Phytopathol. 4:369-390.

4. Fawcett, H. S. 1915. Citrus diseases of Florida and Cuba compared with those of California. Calif. Agric. Exp. Bull. 262

5. Feichtenberger, E., Müller, G. W., and Guirado, N. 1997. Doenças dos citros (Citrus spp.). Pages 289-290 in: Manual de Fitopatologia. H. Kimati, L. Amorim, A. Benjamin Filho, and J. A. M. Rezende, eds. Piracicaba Editora Agronomica Ceres, Piracicaba, Sāo Paulo, Brazil

6. Fisher, F. E. 1961. Greasy spot and tar spot of citrus in Florida. Phytopathology 51:297-303.

7. Graham, J. H., Whiteside, J. O., and Barmore, C. R. 1984. Ethylene production by $M y-$ cosphaerella citri and greasy spot infected citrus leaves. Phytopathology 74:817.

8. Herrera Isla, L., and Garcia Diaz, R. 1975. Observaciones sobre la distribución e intensi- dad de la mancha grasienta (Mycosphaerella citri Whiteside) en naranjo Valencia. Centro Agric. 2:103-111.

9. Hidalgo, H., Sutton, T. B., and Arauz, F. 1997. Epidemiology and control of citrus greasy spot on Valencia orange in the humid tropics of Costa Rica. Plant Dis. 81:1015-1022.

10. Ieki, H. 1986. The causal fungus of greasy spot in Okinawa distinct of Japan. Ann. Phytopathol. Soc. Jpn. 52:484-487.

11. James, J. R., and Sutton, T. B. 1982. Environmental factors influencing pseudothecial development and ascospore maturation of Venturia inaequalis. Phytopathology 72:1073-1080.

12. Johnston, T., and Timmer, L. W. 2004. Evaluation of products for control of citrus greasy spot on red grapefruit, 2002-03. Fungic. Nematicide Tests. Online, Report 59:V027. DOI.10.1094/FN59.

13. Johnston, T., and Timmer, L. W. 2004. Evaluation of products for control of citrus greasy spot on Marsh grapefruit, 2002-03. Fungic. Nematicide Tests. Online, Report 59:V029. DOI.10.1094/FN59.

14. Johnston, T., and Timmer, L. W. 2004. Evaluation of products for control of citrus greasy spot on Redblush grapefruit, 2002-03. Fungic. Nematicide Tests. Online, Report 59:V030. DOI.10.1094/FN59.

15. Koizumi, M. 1986. Sporobolomyces roseus, a causal agent of citrus pseudo greasy spot (Nise-Ohan-Byo) and the infection process of the disease. Am. Phytopathol. Jpn. 52:758-765.

16. Mabbett, T. H., and Phelps, R. H. 1973. Differential susceptibility of grapefruit on various rootstocks to Mycosphaerella citri. Plant Dis. Rep. 57:294-296.

17. Marcó, G. M., and Whiteside, J. O. 1986. A disease similar to greasy spot but of unknown etiology on citrus leaves in Argentina. Plant Dis. 70:1074.

18. Mondal, S. N., Gottwald, T. R., and Timmer, L. W. 2003. Environmental factors affecting the release and dispersal of ascospores of $M y$ cosphaerella citri. Phytopathology 93:10311036.

19. Mondal, S. N., Howd, D. S., Brlansky, R. H., and Timmer, L. W. 2004. Mating and pseudothecial development in Mycosphaerella citri, the cause of citrus greasy spot. Phytopathology 94:978-982.

20. Mondal, S. N., and Timmer, L. W. 2002. Environmental factors affecting pseudothecial development and ascospore production of $M y$ cosphaerella citri $i$ the cause of citrus greasy spot. Phytopathology 92:1267-1275.

21. Mondal, S. N., and Timmer, L. W. 2003. Effect of urea, $\mathrm{CaCO}_{3}$, and dolomite on pseudothecial development and ascospore production of $M y$ cosphaerella citri. Plant Dis. 87:478-483.

22. Mondal, S. N., and Timmer, L. W. 2003. Relationship of epiphytic growth of Mycosphaerella citri to greasy spot development on citrus and to disease control with fenbuconazole. Plant Dis. 87:186-192.

23. Mondal, S. N., and Timmer, L. W. 2005. Ascospore deposition and epiphytic growth in relation to fungicide timing for control of greasy spot rind blotch caused by Mycosphaerella citri. Plant Dis. 89:739-743.

24. Mondal, S. N., and Timmer, L. W. 2006 Relationship of the severity of citrus greasy spot, caused by Mycosphaerella citri, to ascospore dose, epiphytic growth, leaf age, and fungicide timing. Plant Dis. 90:220-224.

25. Mourichon, X., and Zapater, M. F. 1990. Obtention in vitro du stade Mycosphaerella fijiensis, forme parfaite de Cercospora fijiensis. Fruits 45:553-557.

26. Northover, J., and Timmer, L. W. 2002. Control of plant diseases with petroleum- and plant-derived oils. Pages 512-526 in: Spray Oils Beyond 2000. G.A.C. Beattie, D. M. Watson, M. L. Stevens, D. J. Rae, and R. N. 
Spooner-Hart, eds. University of Western Syd-

27. Rodriguez, J. 1978. Mycosphaerella citri, agente causal de la mancha grasienta de los cítricos en Cuba. Ciencia Tecnica Agric. 1(4):99-106

28. Ross, R. G., and Hamlin, S. A. 1962. Production of perithecia of Venturia inaequalis (Cke) Wint. on sterile apple leaf discs. Can. J. Bot. 40:629-635.

29. Rossettii, V. V. 2001. Manual Ilustrado de Doencas de Citros. Fealq/Fundecitrus, Piracicaba, Sāo Paulo, Brazil.

30. Spotts, R. A., Cervantes, L. A., and Niederholzer, F. J. A. 1997. Effect of dolomitic lime on production of asci and pseudothecia of Venturia inequalis and V. pirina. Plant Dis. 81:96-98.

31. Suit, R. F., and DuCharme, E. P. 1971. Cause and control of pink pitting on grapefruit. Plant Dis. Rep. 55:923:926.

32. Sutton, D. K., MacHardy, W. E., and Lord, W. G. 2000. Effects of shredding or treating apple leaf litter with urea on ascospore dose of Venturia inaequalis and disease buildup. Plant Dis. 84:1319-1326.

33. Thompson, W. L. 1948. Greasy spot on citrus leaves. Citrus Ind. 29(4):20-22,26

34. Thompson, W. L., King, J. R., and Deszyak, E. J. 1956. Progress report on greasy spot and its ney, Penrith, Australia.

control. Proc. Fla. State Hortic. Soc. 69:98-104.

35. Timmer, L. W. 2002. Evaluation of fungicides for control of greasy spot on red grapefruit, 1999. Fungic. Nematicide Tests. Online, Report 57:M03.DOI.10.1094/FN57.

36. Timmer L. W., and Gottwald, T. R. 2000. Greasy spot and similar diseases. Pages 25-28 in: Compendium of Citrus Diseases. L. W. Timmer, S. M. Garnsey, and J. H. Graham, eds. American Phytopathological Society, St. Paul, MN.

37. Timmer, L. W., Gottwald, T. R., McGovern, R. J., and Zitko, S. E. 1995. Time of ascospore release and infection by Mycosphaerella citri in central and southwest Florida. Proc. Fla. State Hortic. Soc. 108:374-377.

38. Timmer, L. W., Reeve, R. J., and Davis, R. M. 1980. Epidemiology and control of citrus greasy spot on grapefruit in Texas. Phytopathology 70:863-867.

39. Timmer, L. W., Roberts, P. D., Darhower, H. M., Bushong, P. M., Stover, E. W., Peever, T. L., and Íbañez, A. M. 2000. Epidemiology and control of citrus greasy spot in different citrusgrowing areas in Florida. Plant Dis. 84:12941298.

40. Timmer, L. W., Rogers, M. E., and Buker, R. S., eds. 2005. 2005 Florida Citrus Pest Management Guide. Univ. Florida, Inst. Food \&

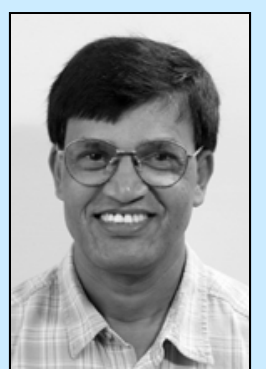

S. N. Mondal

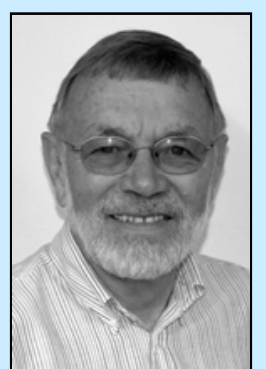

L. W. "Pete" Timmer
Dr. Mondal is currently senior biological scientist in plant pathology at the University of Florida, Citrus Research and Education Center in Lake Alfred. He obtained his B.Sc. (Hons.) in agriculture in 1981 and M.Sc. in plant pathology in 1983 at Bangladesh Agricultural University, Mymensingh, Bangladesh. He started his career as a plant pathologist working on the management of diseases of citrus and vegetables at Bangladesh Agricultural Research Institute in 1983. He received his Ph.D. in plant pathology in 1996 at Gifu University, Japan. His dissertation work involved ecology of root-infecting pathogens. He worked as a research associate for 2 years with his doctoral supervisor, Dr. Mitsuro Hyakumachi, with financial aid from Sun-OInternational, Japan. He joined the University of Florida in 2000 as Assistant in Plant Pathology. His research work focuses on ecology, epidemiology, and control of foliar fungal diseases of citrus.
Dr. Timmer is professor of plant pathology at the University of Florida. He received his B.S. in botany and plant pathology from Michigan State University and his Ph.D. at the University of California at Riverside. He spent two years doing research on citrus diseases in Argentina during his doctoral program. From 1970 to 1978 , he did research and extension on citrus diseases at the then Texas A\&I University Citrus Center (now the Texas A\&M Kingsville Citrus Center) in Weslaco, Texas. Subsequently, he accepted a position with the University of Florida, Citrus Research and Education Center in Lake Alfred, where he is currently employed. His research and extension program focuses on fungal and bacterial diseases of fruit and foliage of citrus trees including etiology, epidemiology, and disease control. For many years, his assignment was $100 \%$ research, but it was changed to $70 \%$ extension three years ago. Dr. Timmer has served terms as associate and senior editor of Phytopathology and associate editor and now, senior editor of Plant Disease. He was senior editor of the Compendium of Citrus Diseases and the Citrus Health Management book. Dr. Timmer received the Lee Hutchins Award for excellence in research on tropical fruit crops and is a Fellow of APS.
Agric. Sci., Publ. No. SP-43.

41. Timmer, L. W., and Zitko, S. E. 1995. Evaluation of nutritional products and fungicides for control of citrus greasy spot. Proc. Fla. State Hortic. Soc. 108:83-87.

42. Trapero-Casas, A., and Kaiser, W. J. 1992. Development of Didymella rabiei, the teleomorph of Ascochyta rabiei, on chickpea straw. Phytopathology 82:1261-1266.

43. Van Brussel, E. W. 1975. Interrelations between citrus rust mite Hirsutella thompsonii and greasy spot on citrus in Surinam. Agric. Res. Rep. 842. Agric. Exp. Stn. Paramaribo, Surinam.

44. Wellings, C. R. 1981. Pathogenicity of fungi associated with citrus greasy spot in New South Wales. Trans. Br. Mycol. Soc. 76:495-499.

45. Whiteside, J. O. 1970. Effect of fungicides applied to citrus trees on perithecial development by the greasy spot fungus in detached leaves. Plant Dis. Rep. 54:865-869.

46. Whiteside, J. O. 1970. Etiology and epidemiology of citrus greasy spot. Phytopathology 60:1409-1414.

47. Whiteside, J. O. 1970. Symptomatology of orange fruit infected by the greasy spot fungus. Phytopathology 60:1859-1860.

48. Whiteside, J. O. 1971. Effectiveness of spray materials against citrus greasy spot in relation to time of application and infection periods Proc. Fla. State Hortic. Soc. 84:56-63

49. Whiteside, J. O. 1972. Blemishes on citrus rind caused by Mycosphaerella citri. Plant Dis. Rep. 56:671-675.

50. Whiteside, J. O. 1972. Histopathology of citrus greasy spot and identification of the causal fungus. Phytopathology 62:260-263.

51. Whiteside, J. O. 1973. Action of oil in the control of citrus greasy spot. Phytopathology 63:262-266

52. Whiteside, J. O. 1973. Evaluation of spray materials for the control of greasy spot of citrus. Plant Dis. Rep. 57:691-694.

53. Whiteside, J. O. 1973. The possibilities of using ground sprays to control citrus greasy spot. Proc. Fla. State Hortic. Soc. 86:19-23.

54. Whiteside, J. O. 1974. Environmental factors affecting infection of citrus leaves by $M y$ cosphaerella citri. Phytopathology 64:115-120.

55. Whiteside, J. O. 1977. Behavior and control of greasy spot in Florida citrus groves. Proc. Int. Soc. Citric. 3:981-986.

56. Whiteside, J. O. 1980. Tolerance of $M y$ cosphaerella citri to benomyl in Florida citrus groves. Plant Dis. 64:300-302.

57. Whiteside, J. O. 1981. Diagnosis of citrus greasy spot based on experience with this disease in Florida. Proc. Int. Soc. Citric. 1:336-340

58. Whiteside, J. O. 1982. Effect of temperature on the development of citrus greasy spot. Proc. Fla. State Hortic. Soc. 95:66-68.

59. Whiteside, J. O. 1982. Timing of single-spray treatments for optimal control of greasy spot on grapefruit leaves and fruit. Plant Dis. 66:687-690

60. Whiteside, J. O. 1983. Fungicidal effects of some acaricides on Mycosphaerella citri. Plant Dis. 67:864-866.

61. Whiteside, J. O. 1983. Viewpoint on the spraying of citrus trees for greasy spot control. Citrus Ind. 64(5):4,6,7,9-11.

62. Whiteside, J. O. 1984. Reliability of spray treatments for greasy spot-induced defoliation on grapefruit trees. Proc. Fla. State Hortic. Soc. 97:56-59.

63. Wilson, A. D., and Kaiser, W. J. 1995. Cytol ogy and genetics of sexual compatibility in Didymella rabiei. Mycologia 87:795-804.

64. Yamada, S. 1956. Studies on the greasy spot (black melanose) of citrus. II. Morphological characteristics of the causal fungus (Mycosphaerella horii Hara). Hortic. Div. Nat. Tokai-Kinki Agric. Exp. Stn. Okitsu, Japan Bull 3. pp. 49-62. 